\title{
DIFFERENTIATION OF THE ECONOMIC VALUE OF POLLINATION OF APPLE ORCHARDS DEPENDING ON THE METHOD OF ESTIMATION
}

\author{
Janusz Majewski ${ }^{1}, \mathrm{PhD}$, Eng. \\ ${ }^{1}$ Warsaw University of Life Sciences - SGGW, Poland
}

\begin{abstract}
Pollinating insects are an important part of the environment. Pollination is an environmental service that affects the yield and quality of entomophilous crops and biodiversity. The aim of the study is to determine the value of pollination of apple orchards in Poland in the years 2005-2017. The following methods were used in the calculations: crop value method, dependency ratio method and replacement costs method.

The results obtained using each of the methods indicate an increase in the value of pollination of apple trees during the study period. In the case of the crop value method, the tested value increased from PLN 1.073 billion (USD 0.332 billion or EUR 0.267 billion) in 2005 to PLN 2.534 billion (USD 0.671 billion or EUR 0.595 billion) in 2017 , in the case of the dependency ratio method, pollination value was equal to $90 \%$ of the value obtained by the crop value method. In the case of the replacement cost method including labour costs at the minimum wage level, the value of pollination increased from PLN 0.648 billion (USD 0.2 billion; EUR 0161 billion) in 2005 to PLN 2.837 billion (USD 0.751 billion; EUR 0.666 billion) in 2017. The highest pollination values were determined using the replacement cost method, taking into account the labour costs at the level of an average wage. These Figures increased from PLN 1.82 billion (USD 0.562 billion; EUR 0.452 billion) in 2005 to PLN 6.054 billion (USD 1.602 billion; EUR 1.422 billion) in 2017. Similar changes were noted in the case of pollination values per hectare of apple orchard. This indicates that the increase in the cultivated area was not a factor determining the increase in the global value of pollination of apple orchards in Poland. In the case of methods taking into account the value of production, the increase in pollination value over time was determined by the increase in apple prices (with significant differences between the years) and the volume of production. In the case of the replacement cost method, the increase in pollination value was influenced by an increase in wages and a gradual intensification of horticulture.
\end{abstract}

Key words: beekeeping, pollination, apple orchards, pollination value.

JEL codes: Q01, Q51, Q57.

\section{Introduction}

The Industrial Revolution in England triggered adverse environmental changes in the world. They intensified in the 20th century. This is manifested by environmental degradation, global warming and depletion of non-renewable natural resources. These changes have led to public interest in the need to maintain balance in the management of natural resources. Various development concepts have been drawn up for this purpose. One of the first was the concept of sustainable development (Poplawski, 2013). This concept concerns mainly rural areas and is related to their multifunctionality and the concept of bioeconomy, which can be defined as a human activity that makes rational use of natural resources for the benefit of people and their environment (Kukula, 2015).

In addition to the possibility of replacing resources, agriculture and rural areas participate in the creation of public goods. When producing public goods, agriculture incurs the costs and does not receive any income from such production. In such case, the economic surplus flows from this sector to the external environment (Czyzewski and Kulyk, 2011). There is a visible market failure. Therefore, the creation of public goods by agriculture should be reflected in agricultural policy, including subsidies for fulfilling non-productive functions. This, in turn, means that the value of the public goods produced needs to be valued.

The pollination of plants by insects, mainly by bees, is a public good. The economic value of pollination is difficult to estimate. This is due, among other things, to differentiated results on the impact of pollination on yields (Breeze et al., 2011; Gallai et al., 2009) and their quality. This can

\footnotetext{
${ }^{1}$ Corresponding author. Tel.: +48 225934 112; fax: +48 225934 101. E-mail address: Janusz_Majewski@sggw.pl
} 
lead to significant differences in the results obtained. The choice of the estimation method also has an impact on the estimated value of pollination of plants. The main methods used to determine pollination value include: market price method, crop value method (CV), dependency ratio method (DR), net income method, cost methods, including the replacement cost method (RC) and consumer surplus method (CS) (Hanley et al., 2015; Mburu et al., 2006; Melathopoulos et al., 2015; Winfree et al., 2011).

The aim of the study is to estimate the value of pollination of apple orchards in Poland in the years 2005-2017 using selected methods. An attempt was also made to evaluate the results obtained and to indicate the factors determining changes in pollination value over time.

The selection of apple orchards for research resulted from their greatest significance for fruit production in Poland. The paper uses data from the Central Statistical Office (GUS), the National Bank of Poland (NBP) and literature on the subject.

\section{Research results and discussion}

The pollination of plants determines the possibility of obtaining crops. In Poland, about $78 \%$ of plant species are pollinated by insects, among which the bee dominates. Beekeepers are generally not paid directly for pollination by bees. Beekeepers' bee products, including honey in particular, may be regarded as payment. The global honey market in the years 2008-2018 grew at a rate of $2 \%$ per annum (Popovych, 2018). However, not all agricultural crops requiring pollination have high honey yields. Therefore, non-market forms of support for beekeeping are also important. A form of aid for beekeepers is the programme introduced by the EU in 1997 to support the beekeeping industry. These funds have had a positive impact on the development of apiculture in EU countries (Jarka and Trajer, 2018; Pawlowski, 2018; Popescu, 2018).

Pollination of cultivated plants is a treatment increasing their yield-forming potential. This treatment may result in an increase in the volume of crops, as well as an improvement in their quality. Other measures, such as cultivation, fertilisation or spraying with plant protection products can only use the yield-forming potential of the plant.

The difficulty of estimating the economic value of pollination of plants results from the difficulty of precise determination of the effects of this measure and the valuation of these effects. For this purpose, a variety of methods can be used, which can most generally be divided into market and non-market ones. Market methods use information available on the market concerning the issue under examination. If the pollination value is determined in this way, it is necessary to collect information on rental prices (in the case of bees) or purchase (in the case of bumblebees) of pollinating insects. The value of pollination in this case will be equal to the price of renting or purchasing insects for pollination. In Poland this value will be low. According to research conducted by Pizlo, among the owners of orchards in the Grojec region only about $3 \%$ of them rented bees for pollination of orchards (Majewski and Pizlo, 2012). This indicates low interest in the paid pollination service, which may result from relatively good natural conditions in Poland, and perhaps also from the lack of knowledge among fruit cultivators about the impact of insects on the yields of fruit plants.

Pollination value studies were carried out in many countries around the world (Table 1). For most of the studies the method of yield values obtained by pollination was applied. The results indicate that pollinating insects are of high importance for agriculture, ranging between GBP 121 and 165 billion per year. When comparing the results of different authors, one can notice a significant variation in the obtained values. This is particularly true of research in the USA. In the case of Poland, the results did not differ significantly (Table 1 ). Significant differences in some of the results obtained 
may result from different approaches to research, the adoption of different assumptions or consideration of different sizes determining the impact of pollinating insects on the yield of cultivated plants. This indicates the need for further research in order to improve testing methodology.

Value of pollination service in selected countries and worldwide according to studies by various authors, in GBP billion in 2010

\begin{tabular}{|l|c|l|c|c|}
\hline \multicolumn{1}{|c|}{ Research Author(s) } & $\begin{array}{c}\text { Publication's } \\
\text { year }\end{array}$ & \multicolumn{1}{|c|}{ Country } & $\begin{array}{c}\text { Pollination value, } \\
\text { in GBP bln (2010) }\end{array}$ & $\begin{array}{c}\text { Method of } \\
\text { estimation* }\end{array}$ \\
\hline Gill & 1991 & Australia & $0.5-0.9$ & DR \\
\hline Brading et al. & 2009 & Egypt & 1.30 & DR \\
\hline Canadian Honey Council & 2001 & Canada & 0.41 & DR \\
\hline Matheson and Schrader & 1987 & New Zealand & 1.83 & CV \\
\hline Zych and Jakubiec & 2006 & Poland & 0.52 & DR \\
\hline Majewski & 2014 & Poland & 0.61 & DR \\
\hline Carreck and Williams & 1998 & Great Britain & 0.32 & DR \\
\hline Robinson et al. & 1989 & The USA & 12.4 & DR \\
\hline Southwick and Southwick & 1992 & The USA & $2.5-8.3$ & DR, CS \\
\hline Morse and Calderone & 2000 & The USA & 12.1 & DR \\
\hline Losey and Vaughn & 2006 & The USA & $2.3 * *$ & DR \\
\hline Calderone & 2012 & The USA & 10.6 & DR \\
\hline Pimtel et al. & 1997 & World & 165.7 & DR, CS \\
\hline Gallai et al. & 2009 & World & 121.8 & \\
\hline
\end{tabular}

* CS - consumer surplus method, CV - crop value method, DR - dependency ratio method.

** Pollination value by indigenous bees. The pollination value of all pollinators was set at GBP 42.6 billion (Losey and Vaughn, 2006).

Source: Hanley et al. 2015; Majewski, 2014

In order to indicate the differentiation of possible results on pollination values depending on the estimation method used, the value of pollination was determined using three methods, i.e. crop value, dependency ratio and replacement costs. In the case of the replacement cost method, the value was identified in two options, which differ in the way in which human labour costs are estimated. In the first option (RC min.), labour costs are set at the level of the minimum wage, and in the second option (RC ave.) at the level of the average wage. In addition, it was assumed that the costs of preparing the workplace, the costs of acquiring pollen for pollination and other costs were included in the pollinating person's wage costs. The data concerning the level of salaries were obtained from the National Bank of Poland.

The pollination value was determined for apple orchards. Apples are one of the most important fruits in the world. They are grown on all continents where horticulture can be found. The choice of apple orchards also resulted from the importance of these crops in Poland and the possibility of applying the replacement cost method, as apple trees are pollinated by insects, mainly by bees (Cuthbertson and Brown, 2006). Information on the area of apple trees cultivation and apple prices was obtained from the Central Statistical Office in Warsaw. On the basis of the literature on the subject, the impact of pollinators on the apple tree yield was determined as $90 \%$. In the case of the replacement cost method, it was assumed that only men can serve as a replacement - this is the case in some parts of China (Mburu et al., 2006; Partap and Ya, 2012). In order to determine the number of people needed for pollination of apple orchards, it was assumed after Allsopp et al. (2008) that it takes on average about 45 minutes for 1 apple tree to be pollinated by a man. The pollination value was also given in dollars and euros to ensure the possibility of comparing the results with those of other authors. Average annual exchange rates from the National Bank of Poland were used for conversions. 
Value of pollination of apple orchards by selected methods in Poland in the years 2005-2017

\begin{tabular}{|c|c|c|c|c|c|c|c|c|c|}
\hline Method & 2005 & 2010 & 2011 & 2012 & 2013 & 2014 & 2015 & 2016 & 2017 \\
\hline \multicolumn{10}{|c|}{ in millions of PLN } \\
\hline CV & 1073.2 & 1200.7 & 2109.2 & 2101.9 & 2759.9 & 1689.7 & 2465.0 & 2105.3 & 2534.2 \\
\hline DR & 965.9 & 1080.7 & 1898.2 & 1891.7 & 2483.9 & 1520.7 & 2218.5 & 1894.8 & 2280.7 \\
\hline RC min & 648.5 & 1224.1 & 1461.8 & 1735.0 & 1959.6 & 2005.6 & 2274.8 & 2506.5 & 2837.1 \\
\hline RC ave & 1819.6 & 2998.0 & 3584.6 & 4073.9 & 4469.9 & 4514.8 & 5070.1 & 5484.6 & 6053.9 \\
\hline \multicolumn{10}{|c|}{ in millions of USD } \\
\hline CV & 331.8 & 398.2 & 711.7 & 645.3 & 873.2 & 535.5 & 653.8 & 533.9 & 670.8 \\
\hline $\mathbf{C R}$ & 298.6 & 358.4 & 640.5 & 580.8 & 785.8 & 482.0 & 588.4 & 480.5 & 603.7 \\
\hline RC min & 200.5 & 405.9 & 493.3 & 532.7 & 620.0 & 635.7 & 603.4 & 635.7 & 751.0 \\
\hline RC ave & 562.5 & 994.1 & 1209.6 & 1250.8 & 1414.2 & 1431.0 & 1344.8 & 1390.9 & 1602.5 \\
\hline \multicolumn{10}{|c|}{ in millions of EUR } \\
\hline CV & 266.6 & 300.6 & 512.0 & 502.2 & 657.5 & 403.7 & 589.2 & 482.6 & 595.2 \\
\hline DR & 240.0 & 270.5 & 460.8 & 452.0 & 591.8 & 363.4 & 530.2 & 434.3 & 535.7 \\
\hline RC min & 161.1 & 306.4 & 354.8 & 414.6 & 466.8 & 479.2 & 543.7 & 574.6 & 666.4 \\
\hline RC ave & 452.0 & 750.5 & 870.1 & 973.5 & 1064.9 & 1078.8 & 1211.8 & 1257.2 & 1421.9 \\
\hline
\end{tabular}

Source: author's own calculation

The value of pollination of apple orchards in Poland, depending on the method used, in 2005 ranged from PLN 0.65 to 1.8 billion, and in 2017 from PLN 2.23 to 6.05 billion (Table 2). The lowest values were obtained for the dependency ratio method and the highest for the replacement cost method - RC ave. In the case of the crop value method and the dependency ratio method, the resulting pollination value is mainly influenced by the crop volume and unit price of the manufactured product, and in the case of the latter also by an indicator determining the share of pollination yield in the total yield. In the case of the replacement cost method, the result is influenced by the time spent on pollination of the unit of area of the crop tested and the cost of employing workers.

It should be noted that in the case of each of the compared methods there is No reference to the analysis of improvement (or deterioration) in the quality of the yield obtained, which also affects its value. Thanks to insects, visiting the same flowers many times for a few days, the resulting fruits are well-developed and healthy. The unit price of such fruit is usually higher than in the case of smaller fruit. On the other hand, pollen is usually supplied once for man-pollinated flowers, which can result in a poorer quality than if insects pollinated the crop.

The estimated value of pollination of apple orchards in Poland in the studied period was characterized by an increase in subsequent years. The fastest growth rate (more than 4-fold increase) of the studied value was recorded in the case of the replacement cost method with the use of the minimum wage ( $R C$ min.), which resulted from the relatively high growth rate of the minimum wage and the number of trees to be pollinated. In the case of the replacement cost method with the use of the average wage ( $R C$ ave.), the value of pollination of apple trees more than tripled between 2005 and 2017 and was twice as high as in the case of the RC min. method. In the case of the other two methods, the value of pollination increased more than twice during the considered period (Table 2).

In the case of the pollination value given in EUR and USD, the trends in all the methods used were similar to the values given in PLN (Table 2). Also the variability of the value estimated in all currencies was similar and ranged from 25 to $36 \%$. 


\section{Average pollination value per hectare of apple orchard in Poland in the years} 2005-2017

\begin{tabular}{|l|r|r|r|r|r|r|r|r|r|c|}
\hline Method & $\mathbf{2 0 0 5}$ & $\mathbf{2 0 1 0}$ & $\mathbf{2 0 1 1}$ & $\mathbf{2 0 1 2}$ & $\mathbf{2 0 1 3}$ & $\mathbf{2 0 1 4}$ & $\mathbf{2 0 1 5}$ & $\mathbf{2 0 1 6}$ & $\mathbf{2 0 1 7}$ \\
\hline \multicolumn{8}{|c|}{ in PLN per hectare } \\
\hline PV & 6325.9 & 7044.8 & 11492.4 & 10796.5 & 14267.7 & 9582.2 & 13664.2 & 11878.6 & 14369.9 \\
\hline DR & 5693.5 & 6340.5 & 10342.9 & 9717.0 & 12840.7 & 8623.9 & 12297.7 & 10690.7 & 12932.7 \\
\hline RC min & 3822.6 & 7181.9 & 7965.1 & 8912.1 & 10130.3 & 11373.8 & 12609.8 & 14142.0 & 16087.7 \\
\hline RC ave & 10725.6 & 17589.5 & 19531.8 & 20926.1 & 23107.5 & 25603.5 & 28104.9 & 30944.8 & 34328.5 \\
\hline \multicolumn{7}{|c|}{ in USD per hectare } \\
\hline PV & 1955.6 & 2336.0 & 3878.1 & 3314.9 & 4514.0 & 3037.0 & 3624.4 & 3012.5 & 3803.9 \\
\hline DR & 1760.1 & 2102.8 & 3490.0 & 2983.4 & 4062.3 & 2733.4 & 3261.7 & 2711.0 & 3423.3 \\
\hline RC min & 1181.8 & 2381.4 & 2687.9 & 2736.3 & 3205.1 & 3605.1 & 3344.8 & 3586.7 & 4258.5 \\
\hline RC ave & 3315.6 & 5832.4 & 6590.9 & 6424.9 & 7310.8 & 8115.2 & 7454.6 & 7847.6 & 9086.9 \\
\hline \multicolumn{7}{|c|}{ in EUR per hectare } \\
\hline PV & 1571.5 & 1763.6 & 2789.6 & 2579.8 & 3399.1 & 2289.5 & 3265.9 & 2722.9 & 3375.1 \\
\hline DR & 1414.7 & 1587.0 & 2510.8 & 2321.8 & 3059.4 & 2060.9 & 2939.0 & 2450.4 & 3037.7 \\
\hline RC min & 949.6 & 1797.7 & 1933.2 & 2129.6 & 2413.2 & 2717.6 & 3013.9 & 3242.0 & 3778.8 \\
\hline RC ave & 2664.3 & 4403.2 & 4741.0 & 5000.5 & 5505.1 & 6117.9 & 6717.3 & 7093.3 & 8062.9 \\
\hline
\end{tabular}

In order to achieve comparability with other results and to better illustrate the changes in the pollination values of apple orchards, the pollination values per hectare of orchards were determined (Table 3). These values are characterised by a slightly lower trend (from 9 to 17 percentage points) in the increase in pollination value between 2005 and 2017 than in the case of the general data. This indicates that the increase in the value of pollination of apple orchards in the years under study resulted to a small extent from the increase in their area. It should be noted that in the case of estimates made using the replacement cost method, the value of pollination in most cases exceeded the value of production.

\section{Conclusions}

Pollination is an environmental service that is important from an agricultural and environmental point of view, as it ensures the maintenance of biodiversity. As a rule, the beekeeper does not receive any payment for its performance. This, in turn, causes their reluctance to place bee colonies close to agricultural crops with low honey yields, such as orchards. As a result, the yields of these plants can be low.

Worldwide studies use many methods to value pollination. Their results may vary and depend on the assumptions and approach to the concept of pollination value. The methods used in the study give different results. However, for all methods there is a clear tendency for the pollination value to increase over time. The highest values were obtained in the case of the replacement cost method and adoption of labour costs at the level of the average wage in the Polish economy. The value obtained by this method was at least twice as high in most of the years under study as in the case of other methods. Relatively high pollination value in the years 2016-2017 was also obtained using the replacement costs method taking into account the costs of the minimum wage. This was due to an increase in the minimum wage and the gradual intensification of orchard production in Poland, which included planting density. 
The increase in the value of pollination under the crop value method and the dependency ratio method resulted from the upward trend in apple prices, which, however, was characterised by significant variability in individual years, and the volume of crop production.

It seems that the method that most fully reflects the value of pollination among the methods used is the dependency ratio method. The problem under this method may be the determination of the extent to which pollinators impact the amount and quality of crops, as pollination is only one of the many treatments that affect the amount of crops. Even in the case of good pollination of crops, the yield may be low due to unfavourable weather conditions, e.g. frost. On the other hand, the replacement cost methods is a hypothetical method because of the impossibility of replacing pollinating insects by humans, not least because of the short flowering period of apple trees and because of this need to employ a significant number of people who would have to deal with pollination.

The conducted research indicates the importance of pollinating insects in fruit production. The estimated values may serve as a basis for determining possible support for beekeeping for the provision of orchard pollination services. It seems necessary to carry out further research to improve the methods of determining this value.

\section{Bibliography}

1. Allsopp, M.H., de Lange, W., Veldtman, R. (2008). Valuing Insect Pollination Services with Cost of Replacement. PloSONE, 3(9) e3128, pp. 1-8.

2. Breeze, T.D., Bailey, A.P., Balcombe, K.G., Potts, S.G. (2011). Pollination Services in the UK. How Important are Honeybbes? Agriculture, Ecosystem and Environment 142(3-4), pp. 137-143.

3. Cuthbertson, A.G.S, Brown, M.A. (2006). Vital Pollinators: Honey Bee in Apple Orchards, Biologist 53(2), pp. 78-81.

4. Czyzewski, A., Kulyk, p. (2011). Dobra publiczne w koncepcji wielofunkcyjnego rozwoju rolnictwa; ujecie teoretyczne i praktyczne (Public Goods in the Concept of Multifunctional Development of Agriculture; Theoretical and Practical Approach), Problemy Rolnictwa Swiatowego 11(2), pp. 16-25.

5. Gallai, M., Salles, J.M., Settele, J., Vaissiere, B.E. (2009). Economic Valuation of the Vulnerability of World Agriculture Confronted with Pollinator Decline, Ecological Economics 68, pp. 810-821.

6. Haney, N., Breeze, T.D., Ellis, C., Goulson, D. (2015). Measuring the Economic Value of Pollination Services: Principles, Evidence and Knowledge Gaps, Ecological Services 14, pp. 124-132.

7. Jarka, S., Trajer, M. (2018). Support for the Beekeeping Sector in Poland and the European Union, Problems of World Agriculture 18(4), pp. 183-191.

8. Kukula, K. (2015). Porownanie miedzyrankingowe panstw UE ze wzgledu na wybrane elementy biogospodarki (Comparisons between Ranking Arrangements within the EU Countries with Respect to Chosen Elements of Bio-Economy in 2012), Problemy Rolnictwa Swiatowego 15(3), pp. 93-101.

9. Losey, J.E., Vaughn, M. (2006). The Economic Value of Ecological Services Provided by Insects, BioScience 56(4), pp. 311-323.

10. Majewski, J. (2014). Economic Value of Pollination of Major Crops in Poland in 2012, Economic Science for Rural Development 34, pp. 14-21.

11. Majewski, J., Pizlo, W. (2012). Znaczenie gospodarcze pszczol w polskim sadownictwie (Economic Significance of Bees in Polish Fruit-Growing), Wies i Rolnictwo 1(154), pp. 146-159.

12. Mburu, J., Hein, L.G., Gemmill, B., Collette, L. (2016). Economic Valuation of Pollination Services: Review of Method, FAO UN, Rome.

13. Melathopoulos, A.P., Cutel, G.Ch., Tyedmers, p. (2015). Where is the Value in Valuing Pollination Ecosystem Services to Agriculture? Ecological Economics 109, pp. 59-70.

14. Partap, U., Ya, T. (2012). The Human Pollinators of Fruit Crops in Maoxim Country, Sichuan, China, Mountain Research and Development 32(2), pp. 176-187.

15. Pawlowski, K.P. (2018). Rola srodkow pochodzacych z Unii Europejskiej w rozwoju pszczelarstwa na przykladzie Wojewodzkiego Zwiazku Pszczelarzy w Poznaniu (The Role of Funds from the European Union in the Development of Beekeeping on the Example of the Provincial Union of Beekeepers in Poznan), Problemy Rolnictwa Swiatowego 18(4), pp. 382-394.

16. Popescu, A. (2018). Honey Production and Trade before and after Romania's Accession into the European Union, Scientific Papers - Series Management Economic Engineering in Agriculture and Rural Development, 18(4), pp. 229-247.

17. Poplawski, L. (2013). Problem wyceny dobr i uslug srodowiskowych na obszarach wiejskich (Problem of Environmental Goods and Services Valuation in Rural Areas), Prace Naukowe Uniwersytetu Ekonomicznego we Wroclawiu 317, pp.250-260. 
Proceedings of the 2019 International Conference "ECONOMIC SCIENCE FOR RURAL DEVELOPMENT" No 52

Jelgava, LLU ESAF, 9-10 May 2019, pp. 363-369

DOI: $10.22616 /$ ESRD. 2019.143

18. Popovych, A. (2018). Zastosowanie modelu grawitacyjnego do analizy miedzynarodowego handlu miodem pszczelim (The Application of the Gravitation Model for Analyzing of International Trade in Bee Honey), Problemy Rolnictwa Swiatowego 18(4), pp. 395-406.

19. Winfree, R., Gross, B.J., Kremen, C. (2011). Valuing Pollination Services to Agriculture, Ecological Economics 71, pp. 80-88. 